\title{
STRUCTURAL AND THERMAL ANALYSIS OF CANNABIDIOL ORODISPERSIBLE FORMULATIONS
}

\author{
ROBERT-ALEXANDRU VLAD ${ }^{1}$, TAMÁS SOVÁNY ${ }^{2}$, KATALIN KRISTÓ ${ }^{2}$, YOUSIF H-E.Y. \\ IBRAHIM $^{2}$, ADRIANA CIURBA ${ }^{1}$, ZOLTÁN AIGNER ${ }^{2}$, DANIELA LUCIA MUNTEAN ${ }^{3 *}$, GÉZA $^{2}$ \\ REGDON JR. ${ }^{2}$
}

I "George Emil Palade" University of Medicine, Pharmacy, Science, and Technology of Târgu Mureș, Faculty of Pharmacy, Pharmaceutical Technology and Cosmetology Department, 38 Gheorghe Marinescu Street, 540142, Târgu Mureș, Romania ${ }^{2}$ University of Szeged, Institute of Pharmaceutical Technology and Regulatory Affairs, 6 Eötvös Street, 6720, Szeged, Hungary

3 "George Emil Palade" University of Medicine, Pharmacy, Science, and Technology of Târgu Mureş, Faculty of Pharmacy, Analytical Chemistry and Drug Analysis Department, 38 Gheorghe Marinescu Street, 540142, Târgu Mureș, Romania

*corresponding author: daniela.muntean@umfst.ro

Manuscript received: November 2020

\begin{abstract}
Cannabidiol (CBD) is an alkaloid that can be found in the Cannabis species, currently used in United States of America under the name of Epidiolex ${ }^{\circledR}$, which was approved by Food and Drug Administration (FDA) for seizures treatment. The purpose of this study was to investigate the structural characteristics of the raw materials and to compare 2 film formulations with different analytical methods. In order to differentiate the structural properties, the following methods were used: X-ray powder diffraction (XRPD) and Fourier transform-infrared (FTIR) spectroscopy. The thermal properties of the raw materials and films was also obtained using differential scanning calorimetry (DSC) and thermogravimetry analysis (TGA). As in the case of structural properties for the thermal decomposition, two films formulations that presented the highest differences were selected. Thermal analysis, FTIR and XRPD were utilized to present the characteristics of the raw materials and the selected orodispersible films.
\end{abstract}

\section{Rezumat}

Canabidiolul (CBD) este unul din alcaloizii ce se regăsește în speciile de Cannabis. Ca produs medicamentos este prezent în Statele Unite ale Americii sub denumirea comercială de Epidiolex ${ }^{\circledR}$ (medicament aprobat de Food and Drug Administration FDA) pentru tratamentul epilepsiei. Scopul acestui studiu constă în prezentarea caracteristicilor structurale ale excipienților, substanței active, respectiv compararea a două formulări de filme orodispersabile prin metode analitice diferite. Pentru a pune în evidență proprietățile structurale ale formularilor s-au folosit următoarele metode: difracția de raze X și spectrometria în infraroșu cu transformată Fourier. Proprietățile termice ale excipienților, substanței active precum și cele ale filmelor au fost analizate utilizând calorimetria cu scanare diferențială și analiza termogravimetrică. La fel ca în cazul analizei proprietăților structurale, și în cazul analizei termice au fost selectate două formulări de filme ce au prezentat proprietăţi distincte. FTIR şi XRPD au fost utilizate pentru a evidenția proprietățile structurale, cele termice fiind evaluate utilizând DSC și ATG.

Keywords: cannabidiol, thermal analysis, infrared spectroscopy, X-ray powder diffractometry, structural analysis

\section{Introduction}

Cannabidiol (CBD), 2-[(1R,6R)-3-methyl-6-prop1-en-2-ylcyclohex-2-en-1-yl]-5-pentylbenzene-1,3diol, is an phytocannabinoid that can be found in the Cannabis sativa species [24]. An oily solution containing CBD called Epidiolex ${ }^{\circledR}$ was approved by FDA in 2018 and represents until now the only approved pharmaceutical formulation worldwide containing only CBD [22]. Epidiolex ${ }^{\circledR}$ has been approved in the treatment of Lennox-Gastaut and Dravet syndromes $[5,7,11]$.

Developing an orodispersible formulation represents a challenge due to the maximum disintegration time that has to be less than a few seconds. Besides the improved bioavailability, an orodispersible formulation in this case orodispersible films (ODFs) may confer other advantages such as: noninvasively route of administration, ease of administration for patients who present physiological impairments such as dysphagia and a fast release of the API [9, 27, 28]. Likewise, good pharmacotechnical and mechanical properties need to be taken into consideration $[1,12]$.

Usually, TG and DSC are used for the characterization of powder and binary mixtures [15]. This method offers an evaluation of the thermal characteristics, dehydration and could be a tool for describing possible interactions between the API and excipients $[6,23]$. It can be used also in the evaluation of the absorption or desorption of water [15]. In our study thermal analysis was conducted to acquire the thermal properties of the powders and two CBD-ODFs. The thermal and structural characterization of ODFs or 
thin films has been used recently to establish the most stable formulation [17].

The present study aimed to evaluate the structural characteristics of the raw materials and two film formulations that with the selected analytical methods presented different properties. To obtain a structural characterization of the films FTIR and XRPD evaluation were made while for thermal analysis, DSC and TG analysis was conducted. Two orodispersible film formulations were selected to highlight the structural and thermal dissimilarities.

\section{Materials and Methods}

\section{Materials}

The materials used were: CBD 99.5\% purity, Trigal Pharma (Austria), Hypromellose (Vivapharm $\mathrm{HPMC}_{\mathrm{E} 3}$ ) which was a kind gift from JRS Pharma (Germany). The other substances used were: citric acid (CA) Fooding (France), sorbitol (SRB) Falken Trade $\mathrm{GmbH}$, (Germany), propylene glycol (PG) SKC Korea, (South Korea) and peach flavour Carmi Flavor and Fragrance (United States of America).

Methods

Preparation of $C B D-O D F s$

The films were prepared by solvent casting method and had a varied composition. The excipients whose concentration was diversified were Vivapharm $\mathrm{HPMC}_{\mathrm{E} 3}$, utilized as a film-forming agent and PG, used as a plasticizer. Water and varied amount of alcohol were used as solvent system. Firstly, the filmforming agent was dissolved into water under continuous stirring at room temperature. After a clear solution was obtained the following components were added: CA, PG, SRB and, PFL. Separately, CBD was dissolved in $96 \%$ alcohol. The obtained alcoholic solution was added over the aqueous solution under continuous stirring drop by drop (Table I). The mixture was cast into a plastic ring having definite thickness and diameters and dried at room temperature for 24 hours (Figure 1). The films were tested within one week after the production process (Table II). The samples were stored in the refrigerator at a temperature of $5 \pm 2{ }^{\circ} \mathrm{C}$ as prevent deterioration and API decomposing.

Table I

Composition of CBD-ODF

\begin{tabular}{lccc}
\hline & \multicolumn{3}{c}{ Concentration of the ingredients (\%) } \\
\cline { 2 - 4 } & F1 & F2 & F3 \\
\cline { 2 - 4 } CBD & 1.25 & 1.25 & 1.25 \\
HPMC & 5 & 5 & 9 \\
PG & 0.5 & 2.5 & 2.5 \\
CA & 1 & 1 & 1 \\
SRB & 1 & 1 & 1 \\
PFL & 1 & 1 & 1 \\
Alcohol & 45.25 & 44.25 & 43.25 \\
Water & 45 & 44 & 42 \\
\hline
\end{tabular}

$\mathrm{CBD}=$ Cannabidiol, $\mathrm{HPMC}_{\mathrm{E} 3}=$ Hypromellose Vivapharm, $\mathrm{PG}=$ propylene glycol, $\mathrm{CA}=$ citric acid, $\mathrm{SRB}=$ sorbitol, PFA = peach flavour Carmi Flavour and Fragrance
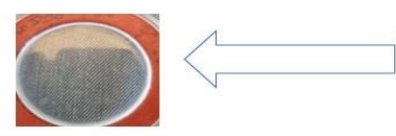

Drying, room temperature -24 h

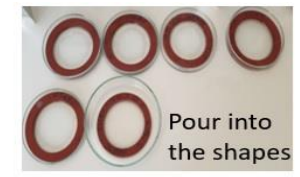

C. Dissolution,

B. Magnetic stirring - $1200 \mathrm{rpm}$ stirring - 1200
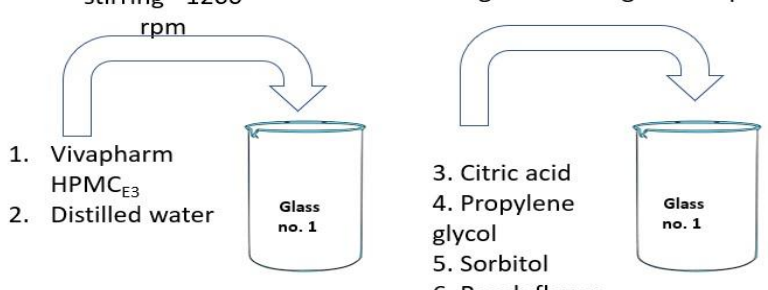

room temperature
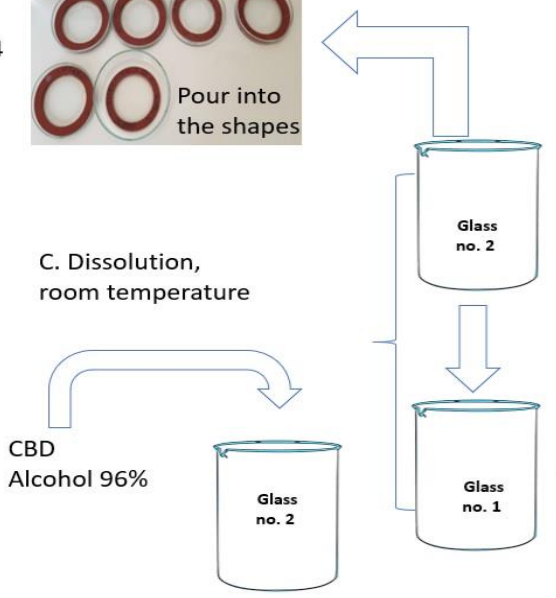

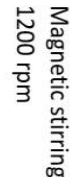

Figure 1.

The process of solvent casting method applied to obtain the CBD-ODFs

Table II

The structural and thermal behaviour described by different analytical methods

\begin{tabular}{lcc}
\hline \multicolumn{1}{c}{ Substance/mixture } & Code & Analytical methods \\
\hline Cannabidiol & CBD & FTIR, XRPD, DSC, TG \\
Vivapharm HPMC E3 $_{\text {Citric acid }}$ & HPMC $_{\mathrm{E} 3}$ & FTIR, XRPD, DSC, TG \\
Sorbitol & CA & FTIR, XRPD, DSC, TG \\
Peach flavour & SRB & FTIR, XRPD, DSC, TG \\
Orodispersible films & PFL & FTIR, XRPD, DSC, TG \\
& F1, F2 & DSC, TG \\
& F1, F3 & FTIR, XRPD \\
\hline
\end{tabular}


Structural analysis

Fourier transform-infrared (FTIR) spectroscopy

The FTIR spectra of the films, CBD and for the excipients were achieved by a FTIR (Avatar 330 FT-IR Thermo Scientific, USA) spectrophotometer. 128 scans in the spectral range of 400 to $4000 \mathrm{~cm}^{-1}$ for raw material and from 600 to $4000 \mathrm{~cm}^{-1}$ for the films, at a spectral resolution of $4 \mathrm{~cm}^{-1}$ were obtained using an EzOMNIC 10.1 software. Three spectra for both raw materials and films were averaged. To obtain the maximum peak linked to different functional groups or representing a characteristic peak for the substance/film; SpectraGryph Software 1.2 was used.

$X$-ray powder diffraction (XRPD) analysis

Crystal/amorphous structure of the excipients, CBD and for F1 and F3 was verified to see if the components are maintaining their characteristics signal after mixing them and obtaining the CBDODFs. For this determination, a Bruker D8 Advance diffractometer was used (Bruker AXS GmbH, Karlsruhe, Germany).

The experiments were performed in symmetrical reflection mode with $\mathrm{Cu} \mathrm{K} \alpha 1$ radiation $(\lambda=1.5406 \AA)$, using Göbel Mirror bent gradient multilayer optics. The scattered intensities were measured with a Våntec-1 line detector. The angular range was from $3^{\circ}$ to $30^{\circ}$ in steps of $0.007^{\circ}$. Other measurement conditions were as follows: target, $\mathrm{Cu}$; filter, $\mathrm{Ni}$; voltage, $40 \mathrm{kV}$; current, $40 \mathrm{~mA}$; measuring time, $0.1 \mathrm{~s}$ per step. F1 and F3 were analysed using this method. Thermal Analysis

Thermogravimetric (TGA) and DSC analysis The TGA and DSC analysis was conducted on powders and films. The thermal analysis of the samples was carried out with a Mettler-Toledo TGA/DSC1 instrument (Mettler-Toledo GmbH, Switzerland). Quantities between $9.51 \mathrm{mg}$ and $10.80 \mathrm{mg}$ of mixtures and films were placed in a closed aluminium crucible with a volume of $40 \mu \mathrm{L}$. The temperature range was between $25-500^{\circ} \mathrm{C}$, the heating rate was $10^{\circ} \mathrm{C} / \mathrm{min}$. Nitrogen atmosphere was used (Cell gas: $50 \mathrm{~mL} / \mathrm{min}$, method gas: $70 \mathrm{~mL} / \mathrm{min}$ ). Evaluation of the curves was acquired with $\mathrm{STAR}^{\mathrm{e}}$ Software. For the TGA and DSC analysis the F1 and F2 CBD-ODFs were examined beside the raw materials.

\section{Results and Discussion}

\section{Structural analysis}

Fourier transform-infrared (FTIR) spectroscopy

FTIR results of the raw materials and the CBDODFs can be found in Figures 2 and 3 and Table III. The substances analysed were: CBD-a cannabinoid, Hypromellose-Vivapharm $\mathrm{HPMC}_{\mathrm{E} 3}$, CA-used as a taste-masking agent [20], saliva stimulating agent [4] while other studies showed that it could be used as a plasticizer [18], SRB-a non-cariogenic sweetener [26], PFL-taste masking agent and flavouring agent. The other two spectra belonged to the ODFs.

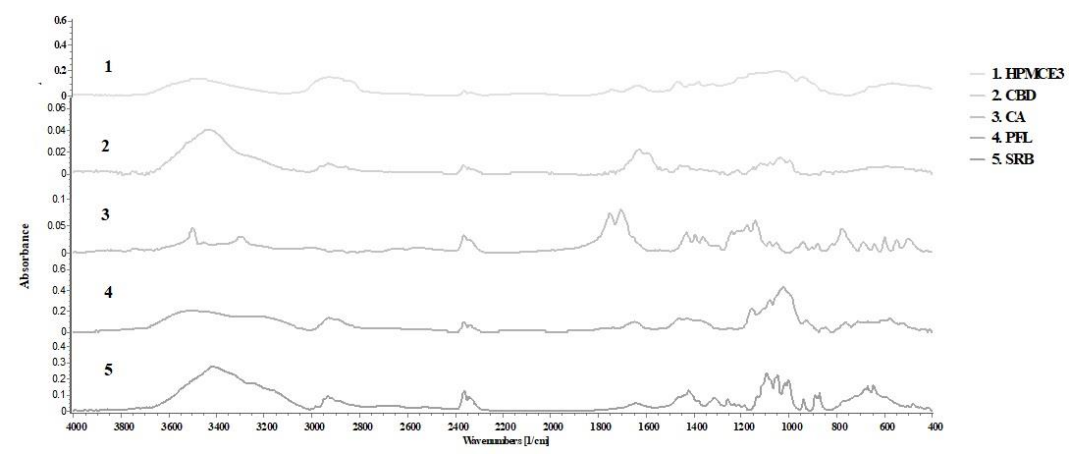

Figure 2.

FTIR spectra of CBD and excipients

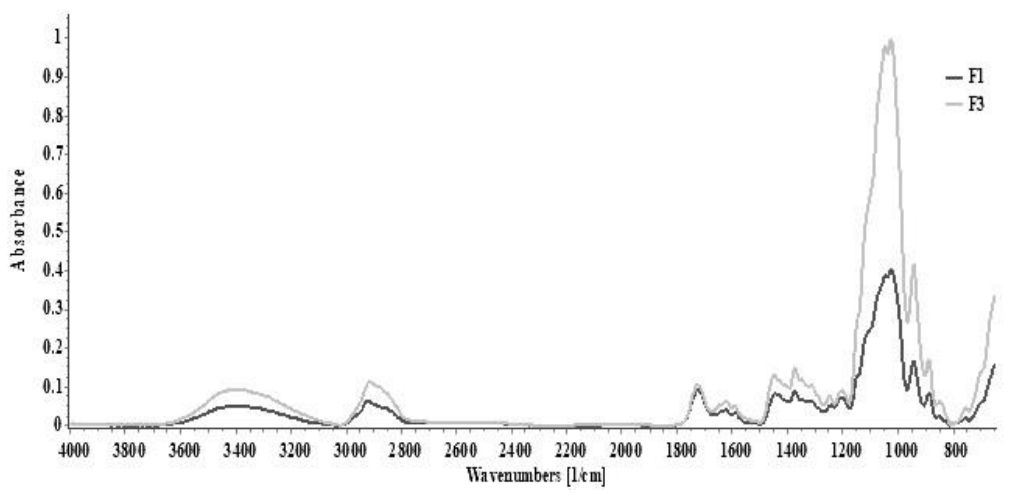

Figure 3.

FTIR spectra of CBD-ODFs 
Wavenumbers of characteristic peaks of the API and the raw materials

\begin{tabular}{ll}
\hline \multicolumn{1}{c}{ Raw material } & \multicolumn{1}{c}{ Wavenumbers of characteristic peaks $\left(\mathbf{c m}^{-1}\right)$} \\
\hline CBD & $3423.3 ; 1620 ; 1638 ; 1590 ; 578$ \\
SRB & $2926.2 ; 1638,1254.1 ; 1095 ; 1048.6 ; 1001 ; 1016,669 ; 644$ \\
HPMC $_{\mathbf{E 3}}$ & $3485 ; 1734 ; 1635 ; 1052 ; 943,75 ; 668 ; 570 ; 472$. \\
CA & $3431 ; 3496 ; 1749 ; 1700 ; 1173 ; 1142 ; 940 ; 880 ; 778 ; 688 ; 640 ; 597 ; 548 ; 498$ \\
PFL & $3485 ; 3238 ; 1645 ; 1737 ; 1780 ; 1154 ; 1080 ; 1023 ; 926 ; 762 ; 708 ; 669 ; 578 ; 525$
\end{tabular}

$\mathrm{CBD}=$ Cannabidiol, $\mathrm{HPMC}_{\mathrm{E} 3}=$ Hypromellose Vivapharm, $\mathrm{CA}=$ citric acid, $\mathrm{SRB}=$ sorbitol, $\mathrm{PFA}=$ peach flavour Carmi Flavour and Fragrance

The presence of the CBD in the films (Figure 3) can be noticed taking into consideration the bands of the $\mathrm{C}=\mathrm{C}$ and $=\mathrm{C}-\mathrm{H}$ aliphatic groups, which were characteristic only to the API. In the formulated films the $\mathrm{C}=\mathrm{C}$ bond appeared while the $\mathrm{F} 3$ was the only film compositions where the $=\mathrm{C}-\mathrm{H}$ did not possess a prominent absorption band. All the FTIR spectra of the films present the following characteristic bands: $2915-2921 \mathrm{~cm}^{-1}$ which represented a tensile vibration given by the $-\mathrm{OH}$. The peak between 1723 $\mathrm{cm}^{-1}$ and $1730 \mathrm{~cm}^{-1}$ is characteristic to the $\mathrm{C}=\mathrm{O}$ stretch which is specific for carboxylic acids. The $\mathrm{C}=\mathrm{O}$ stretch can be representative for the $\mathrm{CA}$ which has three carboxylic groups. The peak at $1443 \mathrm{~cm}^{-1}$ cannot be considered as a particular peak because, it is characteristic to methylene or methoxy groups (asymmetric aliphatic $\mathrm{C}-\mathrm{H}$ deformation), so this peak could belong to the PG, CBD and $\mathrm{HPMC}_{\mathrm{E} 3}$. The absorption band at $1373 \mathrm{~cm}^{-1}$ belongs to a symmetric aliphatic $\mathrm{C}-\mathrm{H}$ bending of methyl groups that can be noticed. It can belong to: CBD, CA, $\mathrm{SRB}, \mathrm{PG}$ and $\mathrm{HPMC}_{\mathrm{E} 3}$. The strong absorption band at $1200 \mathrm{~cm}^{-1}$ can be assigned to the asymmetric stretching of the major function group (C-O-C) can be attributed to PFL and $\mathrm{HPMC}_{\mathrm{E} 3}$.

FTIR spectra showed that even when the final mixture of ODF was obtained the CBD still could be identified and the excipients used did not significantly alter the characteristic bands of the API. Also, characteristic bands were identified for the excipients used in the films.

$X$-ray powder diffraction (XRPD) analysis

XRPD studies for the CBD, excipients and, two film formulations are shown in Figure 4.

Between the solid components, two presented an amorphous state, $\mathrm{PFL}$ and $\mathrm{HPMC}_{\mathrm{E} 3}$ while the active ingredient, CA and SRB showed a crystalline state each one of them offering distinctive peaks at different $2 \theta$ values. The $2 \theta$ angle values characteristic for CBD are: $9.55,10.16,13.36$ and 15.49 , the highest intensity occurring in the case of the 9.55. In addition, the diffractograms of the CA presented the following peaks 17.93 (highest intensity), 19.48, 23.47 and 25.98 while for the other substance that showed also a crystalline structure, SRB, the characteristic peaks were: 18.32 (highest intensity), 20.23 and 25.66. Even though $\mathrm{HPMC}_{\mathrm{E} 3}$ and PFL showed an amorphous structure, $\mathrm{HPMC}_{\mathrm{E} 3}$ offered two signals at 6 and 20
Bragg's angles while PFL presented an increased intensity at 20 Bragg's angles.

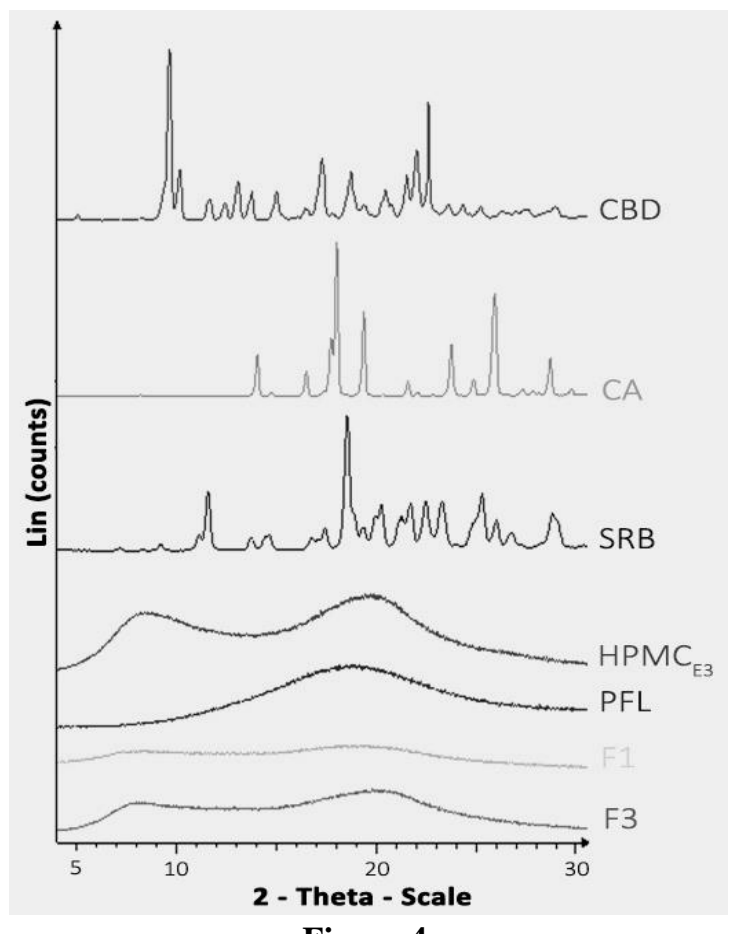

Figure 4.

XRPD patterns of CBD, excipients; F1 and F3 ODFs

The same findings were obtained in the case of CA by Ortega-Toro [10]. The CA presented the same characteristic peaks as the one presented in this paper the only difference consisting in the double dentate peak at 23.47 while our results show only one peak at that $2 \theta$ value. Different peak shapes could be attributed to the following factors: crystallite size, strain, and paracrystallinity [25]. In the same study conducted by Ortega-Toro, a semicrystalline structure could be noticed even after obtaining the films, while in this paper an amorphous mixture resulted [10]. The amount of $\mathrm{HPMC}_{\mathrm{E} 3}$ can be noticed. As a result, in the $\mathrm{F} 3$ the characteristic signal of $\mathrm{HPMC}_{\mathrm{E} 3}$ could be easily observed. As shown in the literature a crystalline structure of the film might be a disadvantage since the stretchability could be affected because of the limited displacement of macromolecule [4]. The amorphous state which can be observed in the case of the CBD-ODFs resulted might be considered an advantage because CBD has a low solubility and 
the $\mathrm{HPMC}_{\mathrm{E} 3}$ can exert solubility enhancing properties as shown in the cases of other poorly water-soluble drugs such as nimodipine [13], carbamazepine [8] and nisoldipine [3].

In the case of SRB, the literature is mixed some of the results showing that an increased concentration of SRB might conduct to a diminished crystallinity as described in Somashekarappa et al. [19], while most of the studies showed that an increased concentration of SRB might conduct to semicristalinity in thin films as stated by Sun et al. [21].

In the case of $\mathrm{F} 1, \mathrm{PG}$ and $\mathrm{HPMC}_{\mathrm{E} 3}$ concentration were the lowest $\left(0.5 \%\right.$ - PG and $\left.5 \% \mathrm{HPMC}_{\mathrm{E} 3}\right)$ while in the $\mathrm{F} 3$ formulation the highest concentrations of $\mathrm{PG}$ and $\mathrm{HPMC}_{\mathrm{E} 3}$ were used $(2.5 \% \mathrm{PG}$ and $9 \%$
$\left.\mathrm{HPMC}_{\mathrm{E} 3}\right)$. Between the two films no major differences were observed, none of them presenting crystalline structure, both being amorphous due to the presence of $\mathrm{HPMC}_{\mathrm{E} 3}$ which is similar to the results obtained by Rotta et al. [14] and Sakata et al. [16].

Thermal analysis

Thermogravimetric analysis

In the present case, TGA was utilized as an evaluation tool (Figure 5). Besides the thermal analysis of the powders, the thermal stability of the CBD-ODFs F1 and $\mathrm{F} 2$ formulations will be discussed.

Thermal decomposition of the CBD, CA and SRB took place in one step, in the case of the film-forming agent in 3 steps while for the films F1 and F2 and for PFL two steps were necessary.

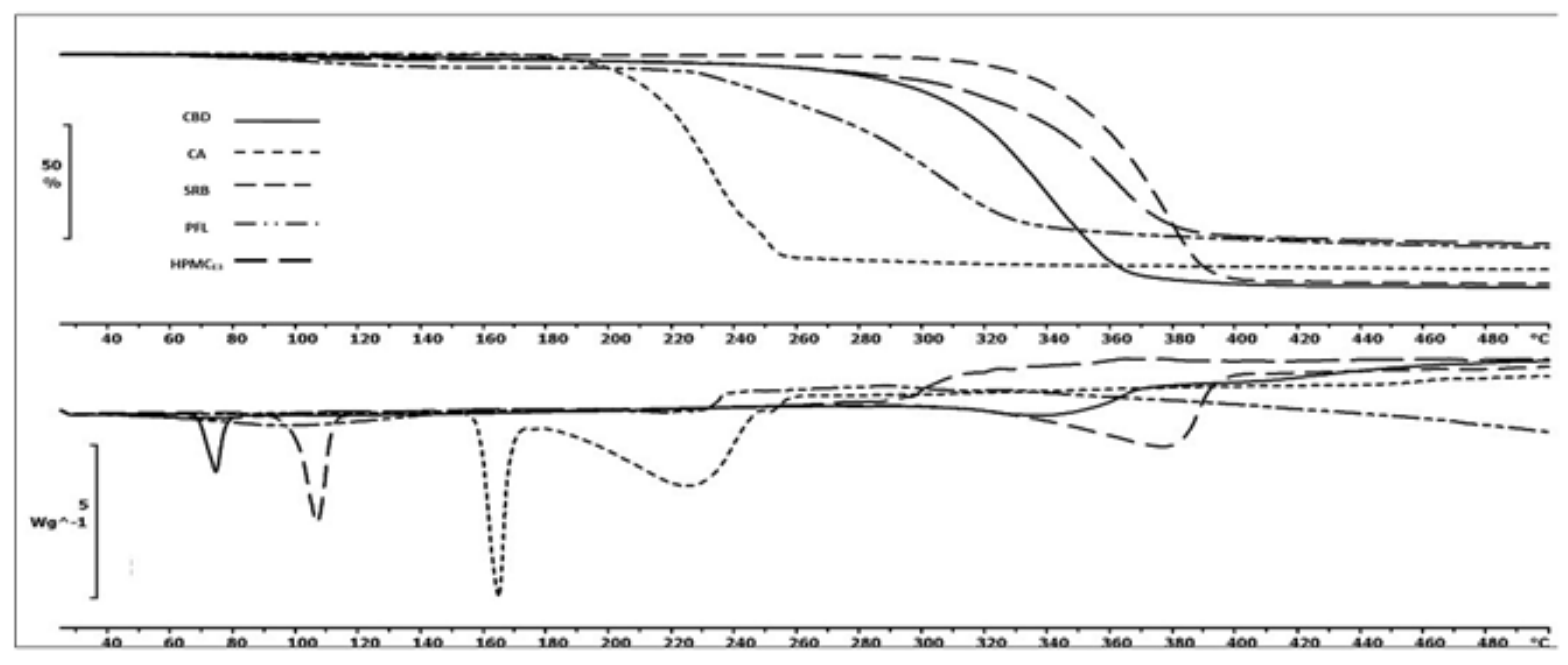

Figure 5.

Differential scanning calorimetry (DSC) and thermogravimetric (TG) curves of CBD and excipients

In both cases the thermal decomposition of the films took place in two steps as in the case of the other amorphous substances used to obtain the CBD-ODFs, the first step usually corresponding to water loss. The other substances that might be involved in this first step thermal mass loss could be alcohol (due to its volatility) and the peach flavour (due to its complex composition). Even though the values of the mass loss are very close in the case of F2 a higher loss can be observed $(89.161 \%)$ while for F1 $(80.565 \%)$ - between 25 and $500^{\circ} \mathrm{C}$. Considering the weight loss percentage, F1 might be considered the most stable film. As can be seen in Figure 6, in both cases the main decomposition starts at temperatures over $160^{\circ} \mathrm{C}$ as a result of the accentuated weight loss. Even though the thermal decomposition of the $\mathrm{HPMC}_{\mathrm{E} 3}$ itself starts at lower temperatures $120^{\circ} \mathrm{C}$, the other film excipients, the film structure and the interactions between the polymer-plasticizer $\left(\mathrm{HPMC}_{\mathrm{E} 3}-\mathrm{PG}\right)$ and polymer-CA $\left(\mathrm{HPMC}_{\mathrm{E} 3}-\mathrm{CA}\right)$ might be an explanation for the higher temperature at which the decomposition starts. The second and third endothermic peak correspond to film-forming agent decomposition as in the case of the fourth peak which was exothermic.

DSC Analysis

The DSC curve (Figure 5) of CBD presented two endothermic processes indicating the melting point at $71.32^{\circ} \mathrm{C}$. The $\mathrm{T}_{\text {onset }}$ was $67.51^{\circ} \mathrm{C}, \mathrm{T}_{\text {endset }}$ was $75.34^{\circ} \mathrm{C}$ and $\Delta \mathrm{H}=60.6 \mathrm{~J} / \mathrm{g}$. The decomposition is indicated by the second endothermic curve which is starting at a higher temperature of $\mathrm{T}_{\text {onset }}$ of $302.99^{\circ} \mathrm{C}$ and a $\mathrm{T}_{\text {endset }}$ of $367.87^{\circ} \mathrm{C}$ with $\mathrm{T}_{\text {peak }} 338.76^{\circ} \mathrm{C}$.

The DSC profile for $\mathrm{HPMC}_{\mathrm{E} 3}$ only one endothermic event could be identified with the peak at $71.40^{\circ} \mathrm{C}$, $\mathrm{T}_{\text {onset }}$ at $40.61^{\circ} \mathrm{C}$ and $\mathrm{T}_{\text {endset }}$ at $101.56^{\circ} \mathrm{C}$ indicating the melting point while the decomposition starts at higher temperatures than $120^{\circ} \mathrm{C}$.

In the case of $\mathrm{CA}$, two large endothermic events were recorded between 154.46 and $162.57^{\circ} \mathrm{C}$ with a $\mathrm{T}_{\text {peak }}=$ $156.69^{\circ} \mathrm{C}$ representing the melting point while the second one revealed the decomposition which started between $182.04^{\circ} \mathrm{C}$ and ended at $242.24^{\circ} \mathrm{C}$ with a $\mathrm{T}_{\text {peak }}=220.47^{\circ} \mathrm{C}$. The same behaviour was registered in the case of SRB were also two endothermic points were recorded. The first endothermic peak 
started at $96.50^{\circ} \mathrm{C}$ and ended at $107.20^{\circ} \mathrm{C}$ with a $\mathrm{T}_{\text {peak }}=100.81^{\circ} \mathrm{C}$ while the second one started at $310.70^{\circ} \mathrm{C}$ and ended at $391.19^{\circ} \mathrm{C}$ with a $\mathrm{T}_{\text {peak }}=$ $374.65^{\circ} \mathrm{C}$. The first peak belonged to the melting point while the second matched the decomposition of the SRB.

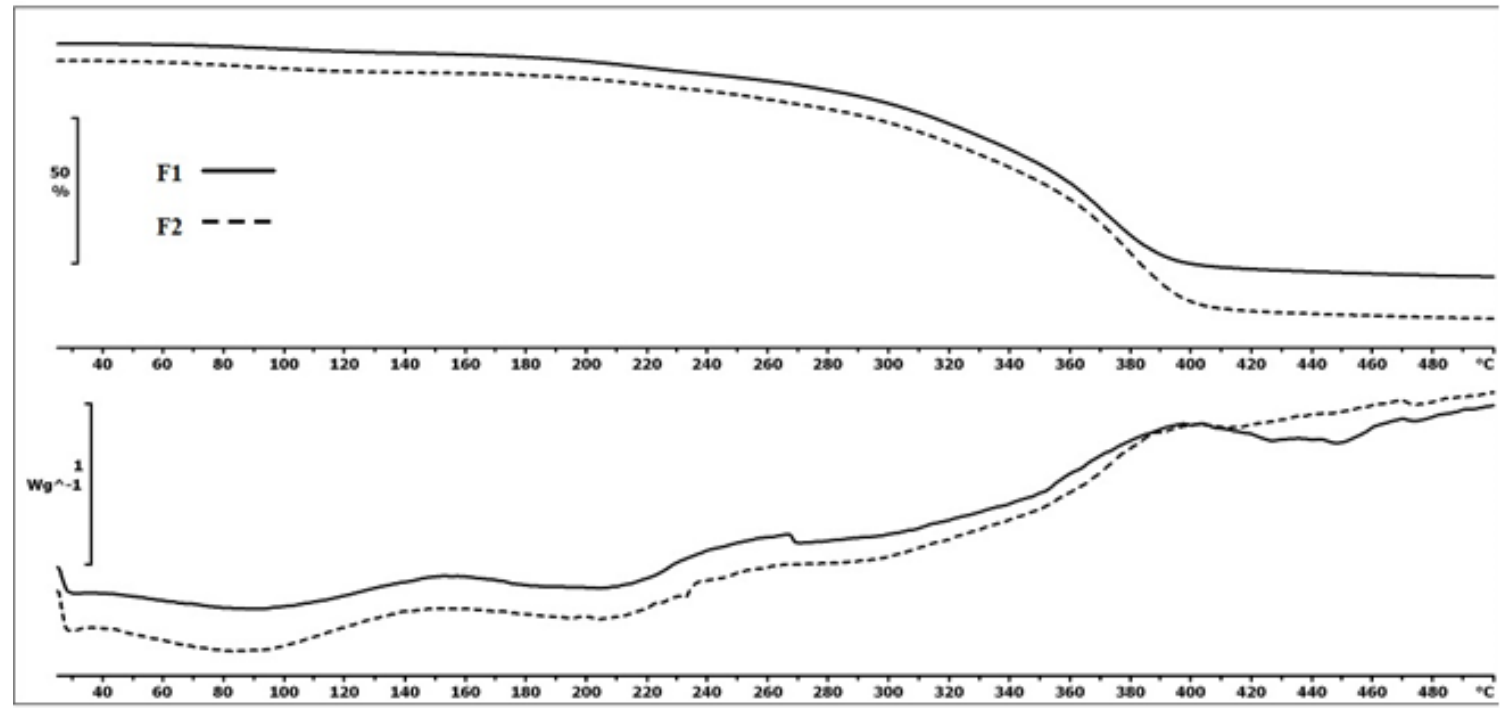

Figure 6.

Differential scanning calorimetry (DSC) and thermogravimetric (TG) curves of F1, F2 CBD-ODFs

For the flavouring agent, two endothermic peaks were recorded with the first corresponding to melting point followed by the second one which belonged to the decomposition. The melting point started at $54.82^{\circ} \mathrm{C}$ and ended at $150.32^{\circ} \mathrm{C}$ with a $\mathrm{T}_{\text {peak }}$ of $96.21^{\circ} \mathrm{C}$

while the decomposition started at $216.80^{\circ} \mathrm{C}$ and ended at $233.76^{\circ} \mathrm{C}$ with a $\mathrm{T}_{\text {peak }}$ of $223.04^{\circ} \mathrm{C}$.

As it can be observed in Figure 6, four thermal events occurred in the case of the F1 and F2 CBD-ODFs studied from which the first three were endothermic while the fourth one was exothermic (Table IV).

Table IV

Thermoanalytical DSC data of F1 and F2 CBD-ODFs

\begin{tabular}{cccccc}
\hline Sample & Peak nr. & $\mathbf{T}_{\text {onset }}\left({ }^{\circ} \mathbf{C}\right)$ & $\mathbf{T}_{\text {endset }}\left({ }^{\circ} \mathbf{C}\right)$ & $\mathbf{T}_{\text {peak }}\left({ }^{\circ} \mathbf{C}\right)$ & $\Delta \mathbf{H}(\mathbf{J} / \mathbf{g})$ \\
\hline F1 & 1 & 84.04 & 136.70 & 89.78 & -55.60 \\
& 2 & 195.49 & 234.80 & 205.98 & -58.51 \\
& 3 & 264.80 & 315.12 & 293.15 & -16.74 \\
& 4 & 320.47 & 425.31 & 391.98 & 109.89 \\
\hline F2 & 1 & 41.87 & 128.30 & 88.69 & -68.59 \\
& 2 & 173.51 & 231.89 & 207.84 & -55.32 \\
& 3 & 266.57 & 320.45 & 293.55 & -11.93 \\
& 4 & 358.78 & 422.74 & 385.74 & 68.41 \\
\hline
\end{tabular}

Taking into consideration the $\mathrm{T}_{\text {onset, }}$ it can be concluded that F2 is a more thermal stable film due to the higher value of $\mathrm{T}_{\text {onset }}$. It has to be mentioned that small differences between the films regarding $\mathrm{T}_{\text {onset }}$ were recorded in the case of some peaks, the biggest difference between the $\mathrm{T}_{\text {onset }}$ of the films being registered in the case of the exothermic peak (over $5^{\circ} \mathrm{C}$ ), while the smallest occurred in the case of the third endothermic peak (less than $1^{\circ} \mathrm{C}$ ). However, the films had the same components so the PG concentration might be responsible for the peaks shifting, because in this case, the concentration of $\mathrm{HPMC}_{\mathrm{E} 3}$ was the same. If the thermal events which occurred in the films are compared it can be stated that for the exothermic peak, $\mathrm{HPMC}_{\mathrm{E} 3}$ and peach flavour might be responsible, since the crystalline substances - CBD, SRB and CA did not present any exothermic events only endothermic ones. The first peak corresponds to water, alcohol and volatile compounds (contained by the PFL) loss, while the second, third and fourth correspond to the decomposition. Also, the interactions between the $\mathrm{PG}$ and $\mathrm{HPMC}_{\mathrm{E} 3}$ might be responsible for the peak shifting and the appearance of the highlighted exothermic peak which could not be easily observed in the case of the amorphous substances. The obtained results are confirmed in terms of enthalpy results.

\section{Conclusions}

Thin films with different compositions of plasticizer and film-forming agents were successfully obtained. The presence of the $\mathrm{HPMC}_{\mathrm{E} 3}$ conducted to an 
amorphous structure which could be observed with XRPD and might be an advantage due to the solubility enhancing properties of the polymer. Structural characterization using FTIR, XRPD and thermal analysis using DSC and TGA proved to be fast screening methods. Although, the CBD-ODFs possess a complex composition, the curve profiles of the thermograms are relatively simple which may imply either an optimal interaction between the components either an overlapping of the thermal event of the components.

\section{Conflict of interest}

The authors declare no conflict of interest.

\section{References}

1. Bîrsan M, Apostu M, Todoran N, Antonoaea P, Rusu A, Ciurba A, Development of dermal films containing miconazole nitrate. Molecules, 2018; 23(7): 1639-1650.

2. Brorsson C, Dahlqvist P, Nilsson L, Naredi S, Saliva stimulation with glycerine and citric acid does not affect salivary cortisol levels. Clin Endocrinol., 2014; 81(2): 244-248.

3. El Maghraby GM, Elsergany RN, Fast disintegrating tablets of nisoldipine for intra-oral administration. Pharm Dev Technol., 2014; 19(6): 641-650.

4. Jiménez A, Fabra MJ, Talens P, Chiralt A, Influence of hydroxypropylmethylcellulose addition and homogenization conditions on properties and ageing of corn starch based films. Carbohydr Polym., 2012; 89(2): 676-686.

5. Laux LC, Bebin EM, Checketts D, Chez M, Flamini R, Marsh ED, Miller I, Nichol K, Park Y, Segal E, Seltzer L, Szaflarski JP, Thiele EA, Weinstock A, Long-term safety and efficacy of cannabidiol in children and adults with treatment resistant Lennox-Gastaut syndrome or Dravet syndrome: Expanded access program results. Epilepsy Res., 2019; 154: 13-20.

6. Leyk E, Wesolowski M, Interactions Between Paracetamol and Hypromellose in the Solid State. Front Pharmacol., 2019; 10: 14: 1-11.

7. MacCallum CA, Russo EB, Practical Considerations in Medical Cannabis Administration and Dosing. Eur J Intern Med., 2018; 49: 12-19.

8. Mitchell SA, Reynolds TD, Dasbach TP, A compaction process to enhance dissolution of poorly watersoluble drugs using hydroxypropyl methylcellulose. Int J Pharm., 2003; 250(1): 3-11.

9. Muntean AC, Negoi OI, Rus LL, Vonica AL, Tomuţă I, Formulation of orodispersible tablets containing paracetamol and their in vitro characterization - A QbD approach. Farmacia, 2020; 68(3): 436-446.

10. Ortega-Toro R, Jiménez A, Talens P, Chiralt A, Properties of starch-hydroxypropyl methylcellulose based films obtained by compression molding. Carbohydr Polym., 2014; 109: 155-165.

11. Pamplona FA, da Silva LR, Coan AC, Potential Clinical Benefits of CBD-Rich Cannabis Extracts
Over Purified CBD in Treatment-Resistant Epilepsy: Observational Data Meta-analysis. Front Neurol., 2018; 9: 759: 1-9.

12. Pechová V, Gajdziok J, Muselík J, Vetchý D, Development of Orodispersible Films Containing Benzydamine Hydrochloride Using a Modified Solvent Casting Method. AAPS PharmSciTech., 2018; 19(6): 2509-2518.

13. Riekes MK, Kuminek G, Rauber GS, de Campos CE, Bortoluzzi AJ, Stulzer HK, HPMC as a potential enhancer of nimodipine biopharmaceutical properties via ball-milled solid dispersions. Carbohydr Polym., 2014; 99: 474-482.

14. Rotta J, Minatti E, Manique Barreto PL, Determination of structural and mechanical properties, diffractometry, and thermal analysis of chitosan and hydroxypropyl-methylcellulose (HPMC) films plasticized with sorbitol. Ciência e Tecnologia de Alimentos, 2010; 31(2): 450-455.

15. Rus LM, Donici E, Valica V, Prisacari V, Tomuță I, Șepeli D, Hegheș SC, Iuga CA, Uncu L, Development, physical-chemical characterization and in vitro antibacterial activity evaluation of a fixed-dose combination isohydrafural-methyluracil hydrophilic ointment. Farmacia, 2019; 67(5): 857-865.

16. Sakata Y, Shiraishi S, Otsuka M, A novel white film for pharmaceutical coating formed by interaction of calcium lactate pentahydrate with hydroxypropyl methylcellulose. Int $J$ Pharm., 2006; 317: 20-126.

17. Senta-Loys Z, Bourgeois S, Valour JP, Briançon S, Fessi H, Orodispersible films based on amorphous solid dispersions of tetrabenazine. Int J Pharm., 2017; 518(1-2): 242-252.

18. Shirai MA, Grossmann MV, Mali S, Yamashita F, Garcia PS, Müller CM, Development of biodegradable flexible films of starch and poly(lactic acid) plasticized with adipate or citrate esters. Carbohydr. Polym., 2013; 92(1): 19-22.

19. Somashekarappa H, Prakash Y, Hemalatha K, Demappa T, Somashekar R, Preparation and Characterization of HPMC/PVP Blend Films Plasticized with Sorbitol. Indian J Materials Sci., 2013; 2013: 307514: 1-7.

20. Sotoyama M, Uchida S, Tanaka S, Hakamata A, Odagiri K, Inui N, Watanabe H, Namiki N, Citric Acid Suppresses the Bitter Taste of Olopatadine Hydrochloride Orally Disintegrating Tablets. Biol Pharm Bull., 2017; 40(4): 451-457.

21. Sun G, Liang T, Tan W, Wang L, Rheological behaviors and physical properties of plasticized hydrogel films developed from $\kappa$-carrageenan incorporating hydroxypropyl methylcellulose. Food Hydrocolloids, 2018; 85: 61-68.

22. Thiele EA, Marsh ED, French JA, MazurkiewiczBeldzinska M, Benbadis SR, Joshi C, Lyons D, Taylor A, Roberts C, Somerville K, Cannabidiol in patients with seizures associated with LennoxGastaut syndrome (GWPCARE4): a randomised, double-blind, placebo-controlled phase 3 trial. Lancet, 2018; 391: 1085-1096.

23. Todoran N, Antonoaea P, Rusu A, Ciurba A, Bîrsan M, Rédai E, DSC and FT-IR Analysis for the Formulation of Dermal Films with Meloxicam in 
FARMACIA, 2021, Vol. 69, 3

Bioadhesive Polymeric Matrices. Rev Chim., 2018; 69(12): 3692-3697.

24. Vlad RA, Farczadi L, Imre S, Ciurba A, Todoran N, Redai E, Antonoaea P, Muntean DL, New UHPLC Method for Cannabidiol Determination in Hard Capsules. Acta Medica Marisiensis, 2019; 65(2): 4548.

25. Widjonarko NE, Introduction to Advanced X-ray Diffraction Techniques for Polymeric Thin Films. Coatings, 2016; 6(4): 54: 1-17.

26. Xavier AF, Moura EF, Azevedo WF, Vieira FF, Abreu MH, Cavalcanti AL, Erosive and cariogenicity potential of pediatric drugs: study of physicochemical parameters. BMC Oral Health, 2013; 13: 71: 1-7.

27. Yoshita $\mathrm{T}$, Uchida S, Namiki N, Clinical disintegration time of orally disintegrating tablets clinically available in Japan in healthy volunteers. Biol Pharm Bull., 2013; 36: 1488-1493.

28. Yan TT, Lv ZF, Tian P, Lin MM, Lin W, Huang SY, Chen YZ, Semi-solid extrusion 3D printing ODFs: an individual drug delivery system for small scale pharmacy. Drug Dev Ind Pharm., 2020; 46(4): 531-538. 